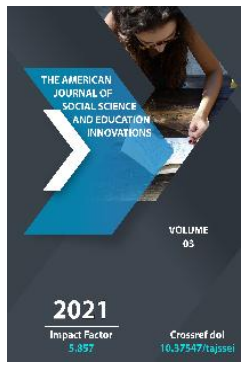

Journal Website: http://theamericanjour nals.com/index.php/taj ssei

Copyright: Original content from this work may be used under the terms of the creative commons attributes 4.0 licence.

\section{Lexical And Grammatical Features Of The Compilation Of The RCT Textbook (Russian As A Foreign Language)}

\author{
Berdieva Mukarrama Anvarovna \\ Candidate Of Pedagogical Sciences, Associate Professor, Head Of The Department Of Russian \\ Language Yedzhu Technical Institute In Tashkent, Uzbekistan
}

Bazarova Shohida Ashirkulovna

Teacher National University, Uzbekistan

\title{
ABSTRACT
}

The article considers the system of principles for creating a modern textbook for adults as a basic linguodidactic tool in teaching Russian to foreigners at an advanced stage of training, with the focus of the educational process on the formation of intercultural competence. Russian language textbook for foreigners contains topics and situations of reality that are relevant to Russian linguoculture in their verbal embodiment in texts of different genres and styles of the modern Russian language. The author demonstrates that with a cognitive-communicative approach, the discursive base of the textbook on the Russian language for foreigners contains relevant topics and situations of reality in their verbal embodiment in texts of different genres and styles of the modern Russian language.; the linguistic concept of the textbook is based on the achievements of theoretical Russian studies; the methodological interpretation of the educational material reflects the understanding of the experience of teaching Russian to foreigners. The textbook serves as a basis for creative use both by the teacher in the educational process and by the students in their independent work, which plays a crucial role in learning. The author emphasizes the importance of the modern textbook as a means of improving the professional competence of the teacher. The author notes that the textbook takes into account the specifics of the forms and norms of modern communication, including the use of information and communication technologies. The textbook is based on clearly defined goals based on the internal motivation of students, focuses on the development and improvement of their communication skills with the active cooperation of the teacher and the student.

\section{KEYWORDS}

Russian language, Communicative, Lexical And Grammatical , RCT , Textbook. 
The article deals with the system of principles of creating a modern textbook for adults as a basic didactic tool in teaching Russian to foreigners at an advanced stage, when the educational process is aimed at the formation of intercultural communicative competence. The author demonstrates that the cognitive and communicative approach of the discourse base of the textbook on Russian for foreigners contains relevant for the Russian linguistic culture topics and situations of reality in their verbal embodiment in the texts of different genres and styles of modern Russian language; the linguistic concept of the textbook is based on the achievements of theoretical Russian studies; methodical interpretation of the educational material reflects the understanding of the experience of teaching Russian to foreigners. The textbook serves as a basis for creative use as a teacher in the educational process, and students in his independent work, which has a decisive role in learning. The author emphasizes the importance of the modern textbook as a means of improving the professional competence of the teacher. The author notes that the textbook takes into account the specifics of forms and norms of modern communication, including the use of information and communication technologies. The textbook demonstrates clearly defined goals based on the internal motivation of students, focuses on the development and improvement of their communication skills with the active cooperation of the teacher and student.

The modern method of teaching Russian as a foreign language, which was formed in the 50-60s of the XX century, is associated with the name of the famous psychologist and methodologist B. V. Belyaev, who justified the method, whichwas called consciously practical.

Russian language was developed in a relatively short period of time by adults, who were expected to master the basics of the language necessary for communication in the Russian language environment, as well as for higher education.20 The need to develop a conscious and practical method was due to the fact that adults came to study Russian, as a rule, who had to master the basics of the language in a relatively short time, which were necessary for communication in the Russian language environment, as well as for obtaining higher education. They had an average of education and sometimes knew one or two foreign languages. In this situation, the conscious-practical method was most effective.

The initial point in the study of the language was the task of mastering knowledge about the system of the language being studied, in our case, Russian, and about the conditions of its functioning in various situations and styles. Language knowledge was recommended to be reported using sentence models and speech patterns.

A little earlier, in the practice of teaching foreign languages, a consciously comparative method was used, which is based on the principles of consciousness and reliance on the native language of students were laid down. But its full application was not possible, since the teachers of the RCT, as a rule, did not know the language of the students: often they were the languages of the peoples of Africa and South-East Asia. A modified version of the conscious-comparative method is recognized as the method of nationallanguage orientation by V. N. Wagner.21 
The method of B. V. Belyaev remains the leading one in teaching the Russian language as a foreign language in the conditions of prolonged training and is especially recommended for students of philological specialties, since it is it provides not only a practical orientation, but also a theoretical understanding of the facts of the language.

The main task of teaching Russian as a foreign language was recognized as the task of teaching a foreigner to communicate in the language being studied.

It was recommended that at least $85 \%$ of the study time should be devoted to speech practice, and it should be non-translational.

The teaching of foreign language speech began with the teaching of listening and speaking: one of the main principles was the principle of oral advance.

It was necessary to move from oral speech to written speech.

It was recommended to develop the types of speech activity in parallel.

\section{REFERENCES}

1. Resolution of the President of the Republic of Uzbekistan No. PP-3080 of June 23, 2017 "On measures to establish the Center of Islamic Culture in Uzbekistan under the Cabinet of Ministers of the Republic of Uzbekistan."

2. Osman Ode. Myth and literature. http://kitapcy.com

3. Berdak. Selected works. - Nökis: Karakalpakstan, 1997. - 164 p.

4. Ajiniyaz. Works. - Nökis: Karakalpakstan, 1975. - $182 \mathrm{p}$.

5. Magtymguly. A collection of works. Volume II. Ashgabat, MGI, 2013, p.126.
6. Rakhmanov N., Boltaboev H .. Creation of man.//Samples of classic Uzbek literature. 1 year. - Tashkent: Fan, 2003. - pp. 14-15. 